\title{
NEW RECORD OF THE SPINY PUFFERFISH, TYLERIUS SPINOSISSIMUS (REGAN, 1908), FROM ISRAEL, GULF OF AQABA, RED SEA (ACTINOPTERYGII: TETRAODONTIFORMES: TETRAODONTIDAE)
}

\author{
Ronald FRICKE ${ }^{1,2}$, Daniel GOLANI ${ }^{3}$, Brenda APPELBAUM-GOLANI ${ }^{4}$, and Uwe ZAJONZ ${ }^{5,6}$ \\ ${ }^{1}$ Im Ramstal 76, 97922 Lauda-Königshofen, Germany \\ ${ }^{2}$ Staatliches Museum für Naturkunde, Rosenstein 1, 70191 Stuttgart, Germany [temporarily out of office] \\ ${ }^{3}$ National Natural History Collections and Department of Ecology, Evolution and Behavior, The Hebrew University \\ of Jerusalem, 91904 Jerusalem, Israel \\ ${ }^{4}$ Mt. Scopus Library, The Hebrew University of Jerusalem, 91905 Jerusalem, Israel \\ ${ }^{5}$ Senckenberg Forschungsinstitut und Naturmuseum, Sektion Ichthyologie, Senckenberganlage 25, 60325 Frankfurt \\ am Main, Germany
}

${ }^{6}$ Senckenberg Biodiversität und Klima Forschungszentrum, Forschungsbereich Ökosystemleistungen und Klima, 25, 60325 Frankfurt am Main, Germany

Fricke R., Golani D., Appelbaum-Golani B., Zajonz U. 2016. New record of the spiny pufferfish, Tylerius spinosissimus (Regan, 1908), from Israel, Gulf of Aqaba, Red Sea (Actinopterygii: Tetraodontiformes: Tetraodontidae). Acta Ichthyol. Piscat. 46 (2): 115-118.

\begin{abstract}
The spiny pufferfish, Tylerius spinosissimus (Regan, 1908), is recorded for the first time from the Gulf of Aqaba, Red Sea, based on a specimen collected off Eilat, Israel at a depth of 350-400 m. This finding also confirms the occurrence of the species in the Red Sea which was previously based on an unsubstantiated record.
\end{abstract}

Keywords: pufferfish, new record, Red Sea, Israel, distribution

The spiny pufferfish, Tylerius spinosissimus (Regan, 1908), is widely distributed in the Indo-West Pacific (Regan 1908, Saya-de-Malha Bank; Hardy 1981, off north-western Australia; Kyushin et al. 1982, South China Sea; Hardy 1984, Alas Strait, off Sumbawa, Indonesia; Smith and Heemstra 1986, KwaZulu-Natal, South Africa; Mohsin and Ambak 1996, Malaysia; Matsuura and Tyler 1997, New Caledonia; Shao et al. 2008, Taiwan; Fricke et al. 2009, Réunion; Larson et al. 2013, Northern Territory, Australia; Fricke 2015, Morobe, Papua New Guinea). Outside this range, the species was recorded from Hurghada, Red Sea by Budker and Fourmanoir (1954: 324, as "Amblyrhynchotes spinosissimus"), listing the species without any further data. This Red Sea record was cited but not discussed by several authors, but as no specimen was available and no information about the record had been provided, Golani and Bogorodsky (2010: 86) came to the conclusion that the record of $T$. spinosissimus could not be confirmed.
The genus Tylerius Hardy, 1984 is monotypic and contains Tylerius spinosissimus (Regan, 1904) as the single species (Hardy 1984). It is characterised from other tetraodontid genera, especially from the closely related genus Amblyrhynchotes Troschel [ex Bibron], 1856, by the nasal papilla bearing two nostrils, only the dorsal eye rim adnate, no ventrolateral fold of skin, and the presence of well developed upper and lower lateral lines extending along the body to the caudal-fin base.

A specimen of Tylerius spinosissimus from the northern Red Sea was recently identified in deep water materials of the HUJ collection; it is described in the present paper. The earlier unsubstantiated Red Sea record of this species can now be confirmed.

On 9 July 1992, a $38.6 \mathrm{~mm}$ SL specimen of Tylerius spinosissimus was collected by Albert Baranes off Eilat, Israel, Gulf of Aqaba, Red Sea, with a beam trawl at 350$400 \mathrm{~m}$ depth. The specimen was deposited in the Hebrew University Fish Collection and registered under the

* Correspondence: Dr. Ronald Fricke, Im Ramstal 76, 97922 Lauda-Königshofen, Germany, phone: +49 9343 600801, e-mail: (RF) ronfricke@web.de, (DG) dani.golani@mail.huji.ac.il, (BAG) brendag@savion.huji.ac.il, (UZ) uzajonz@senckenberg.de. 
catalogue number HUJ 17441. Counts and measurements follow Hubbs and Lagler (1947); the classification follows Eschmeyer et al. (2016), description details follow Hardy (1981), fin-ray counts follow Fricke (1983), references according to Fricke (2016). The standard length is abbreviated as SL the head length as HL.

\section{Family Tetraodontidae Bonaparte, 1831 Genus Tylerius Hardy, 1984 \\ Tylerius spinosissimus (Regan, 1908)}

Description of the Red Sea specimen: Proportions given in Table 1 are part of this description. Dorsal-fin rays viii, anal-fin rays vi, pectoral-fin rays xvi, caudal-fin rays xi. Body elongate, barely flattened ventrally, tapering to short, narrow caudal peduncle; mouth small, terminal; lips covered with numerous short papillae; chin lacking; nasal organ short, flattened papilla, set in slight depression just forward to eye, distally with 2 moderately separated, similarly sized opening; eye moderate, round and dorsally adnate only, upper border below dorsal profile, lower border well above corner of mouth; prebranchial margin smooth.

No obvious ventrolateral skin fold; lateral line fairly distinct, encircling eye with anterodorsal branch anterior to nasal organ but failing to meet in midline, and preopercular branch dropping towards lateral limit of belly, extending along body to caudal fin, rising high over pectoral fin and gently dropping under dorsal fin; mid-dorsal branch of lateral line above pectoral fin not meeting in midline; second lateral line dropping from behind corner of mouth, extending along lateral region of belly except for break ventral to pectoral fin.

Body spines 2-rooted, well developed and moderately dense, extending dorsally and laterally from before nasal organs almost to caudal-fin base, and extending ventrally from chin region to anal fin.

Pectoral fins dorsally elongate and rounded; top of base well below lower margin of eye; first ray moderately long; dorsal fin elongate and bluntly pointed, based directly above vent; anal-fin base short, anal-fin rays partly fused; caudal fin truncate.

Colour after 24 years in preservative (Figs. 1-2): Head and body brown; lower sides of body and belly pale, scattered with minute dark brown spots; eye dark grey; fins yellowish, caudal fin distally dark grey.

Remarks. Tylerius spinosissimus was first described by Regan(1908:253,pl.31,fig. 5, "Spheroides spinosissimus") from deep water off the Saya de Malha Bank, western Indian Ocean (holotype: BMNH 1908.3.23.299). The species was reviewed and redescribed in detail based on the holotype and additional specimens from off Western Australia by Hardy (1981: 313, as “Amblyrhynchotes

Table 1

Meristic data and proportions of two specimens of Tylerius spinosissimus (HUJ 17441, 38.6 mm SL, 9 July 1992, Eilat, Israel, Gulf of Aqaba, Red Sea; HUJ 19946, 27.3 mm SL, 5 May 2010, Tel Aviv-Ashdod, Israel, Mediterranean Sea)

\begin{tabular}{|c|c|c|c|c|}
\hline & \multicolumn{2}{|c|}{ Measurement in $\mathrm{mm}$} & \multicolumn{2}{|c|}{ Proportion in SL: } \\
\hline & HUJ 17441 & HUJ 19946 & HUJ 17441 & HUJ 19946 \\
\hline Standard length (SL) & 38.6 & 27.3 & -- & -- \\
\hline Head length (HL) & 14.6 & 11.1 & 2.6 & 2.5 \\
\hline Snout to anterior of vent & 27.7 & 19.9 & 1.4 & 1.4 \\
\hline Snout to origin of dorsal fin & 27.4 & 18.7 & 1.4 & 1.5 \\
\hline Snout to origin of anal fin & 30.8 & 20.7 & 1.3 & 1.3 \\
\hline Snout to origin of pectoral fin & 16.5 & 12.6 & 2.3 & 2.2 \\
\hline Width at base of pectoral fin & 12.6 & 5.6 & 3.0 & 4.9 \\
\hline Depth from dorsal-fin origin to anal-fin origin & 5.1 & 5.1 & 7.6 & 5.4 \\
\hline Depth at posterior of dorsal fin & 3.7 & 4.1 & 10.4 & 6.7 \\
\hline Caudal-peduncle length & 4.8 & 6.7 & 8.0 & 4.1 \\
\hline Least depth of caudal peduncle & 2.8 & 1.8 & 13.8 & 15.2 \\
\hline Maximum length of pectoral fin & 5.9 & 2.6 & 6.5 & 10.5 \\
\hline Length of first pectoral-fin ray & 3.8 & 0.5 & 10.1 & 54.6 \\
\hline Length of longest anal-fin ray & 3.9 & 3.6 & 9.9 & 7.6 \\
\hline Length of anal-fin base & 0.7 & 2.6 & 55.1 & 10.5 \\
\hline Length of longest pectoral-fin ray & 5.1 & 3.3 & 7.6 & 8.3 \\
\hline Length of pectoral-fin base & 3.3 & 1.9 & 11.7 & 14.4 \\
\hline \multirow[t]{2}{*}{ Maximum caudal-fin length } & 11.5 & 9.2 & 3.4 & 3.0 \\
\hline & & & \multicolumn{2}{|c|}{ Proportion in HL: } \\
\hline Mouth width & 4.1 & 2.2 & 3.6 & 5.0 \\
\hline Nasal organ length & 1.1 & 0.7 & 13.2 & 15.9 \\
\hline Snout to anterior edge of nasal organ & 3.3 & 2.4 & 4.4 & 4.6 \\
\hline Posterior edge of nasal organ to anterior edge of eye & 0.7 & 0.7 & 20.8 & 15.6 \\
\hline Horizontal eye diameter & 7.9 & 4.3 & 1.8 & 2.6 \\
\hline Least fleshy interorbital distance & 1.9 & 1.9 & 7.7 & 5.8 \\
\hline Posterior of eye to dorsal corner of gill opening & 5.5 & 4.1 & 2.6 & 2.7 \\
\hline
\end{tabular}


spinosissimus"). Hardy (1984: 32) placed the species in a separate, new genus Tylerius Hardy, 1984.

Budker and Fourmanoir (1954: 324, "Amblyrhynchotes spinosissimus") were the first to report the species from Hurghada (Egypt, Red Sea) in a species list without a description or supporting specimens in a collection. This record was repeatedly listed by Dor (1984: 253) and Goren and Dor (1994: 74). Golani and Bogorodsky (2010: 86) noted that the species "does not occur in the Red Sea," and that "Budker and Fourmanoir's (1954) record is evidently a misidentification of Arothron diadematus (Rüppell, 1829)." However, several records of Tylerius spinosissimus from Rhodes (Corsini et al. 2005, Corsini-Foka et al. 2010), Israel (Golani et al. 2011), and Iskenderun Bay, Turkey (Turan and Yaglioglu 2011) in the eastern Mediterranean suggest that the species is a Lessepsian migrant and does occur in the Red Sea.

During the examination of tetraodontid fishes in the HUJ collection, the authors of the present paper discovered a specimen from off Eilat, Israel, collected in 1992 which they identified as Tylerius spinosissimus. The Red Sea record of that species can therefore now be confirmed; this also represents a first record from Israel and the Gulf of Aqaba, and adds to the knowledge of deep water species of the Red Sea. The species has not yet been recorded from the coast of Jordan (Khalaf and Zajonz 2007), and is neither present in the German deep-sea expeditions to the Red Sea, MESEDA I-III and MINDIK (Türkay 1996; fish identifications see Zajonz 2006, and an unpublished faunal account by Uwe Zajonz).

There are slight differences to the specimens described by Hardy (1981), i.e., in the anal-fin ray number (6 versus 7) and proportions of the caudal peduncle and the snout. Another specimen recently recorded from the Mediterranean coast of Israel by Golani et al. 2011 (HUJ 19946, 1 specimen, $27.3 \mathrm{~mm}$ SL, Israel, AshdodTel Aviv, trawl at 120-140 m depth, Dor Edelist, 5 May 2010; proportions see Table 1) shows similar differences to the specimens described by Hardy (1981). Additional material is needed to examine the variability of Red Sea/ Mediterranean Sea populations, and to decide if they are distinct from T. spinosissimus sensu stricto.

The presently described specimen was collected with a beam trawl at 350-400 m depth, possibly above sand bottom. The new distribution record of Tylerius spinosissimus from the Red Sea adds to the picture of a wide Indo-West Pacific and Red Sea distribution range of this species (Fig 3). This deep water species is rarely collected, and apparent gaps in the known distribution range probably just reflect the absence of deep water fish collections in many parts of the range.

In the Red Sea, other suitable habitats for this species are found throughout the lower continental shelf of the main body and the Gulf of Aqaba. The species probably dispersed into the eastern Mediterranean Sea through the Suez Canal by means of its pelagic larvae; the existing records from three distant areas in the Mediterranean suggest that the species has already established reproducing populations, and additional records are expected.

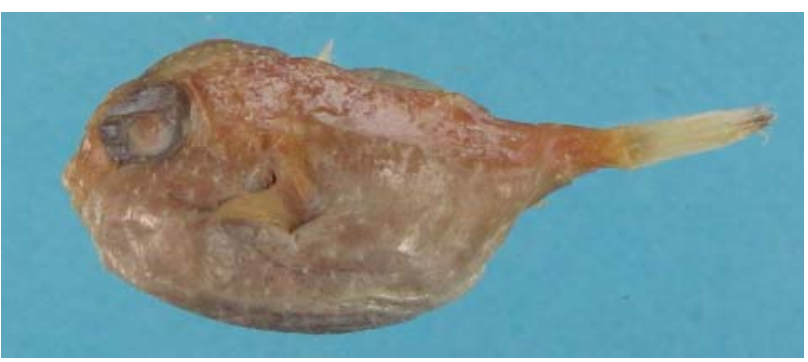

Fig. 1. Tylerius spinosissimus, Lateral view; HUJ 17441, 38.6 mm SL, 9 July 1992, Eilat, Israel, Gulf of Aqaba, Red Sea; Photograph by Daniel Golani

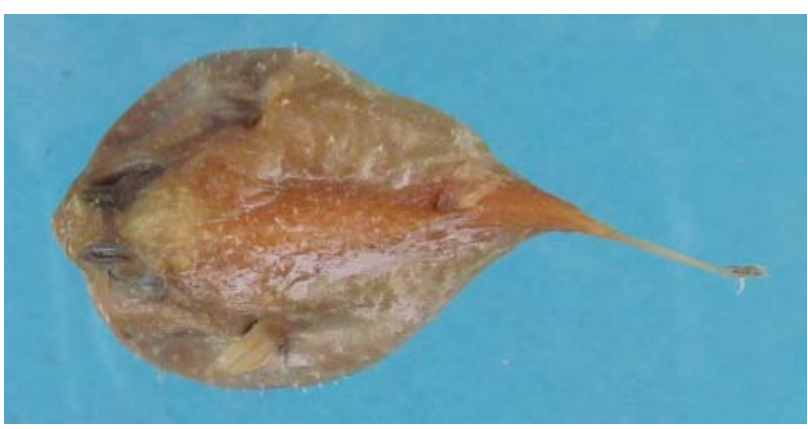

Fig. 2. Tylerius spinosissimus, Dorsal view; HUJ 17441, 38.6 mm SL, 9 July 1992, Eilat, Israel, Gulf of Aqaba, Red Sea; Photograph by Daniel Golani

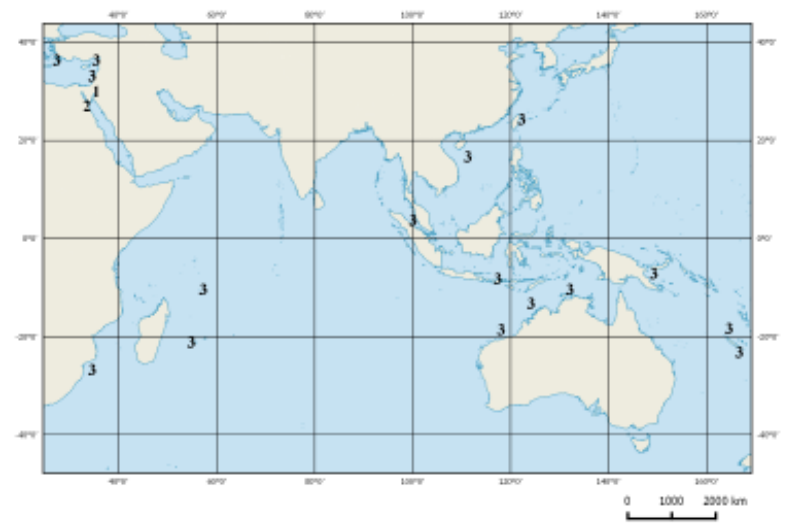

Fig. 3. Tylerius spinosissimus, map of the Indo-West Pacific, Red Sea and eastern Mediterranean Sea with the known distribution of the species; $\mathbf{1}=$ new record from Gulf of Aqaba; 2 = Egyptian record by Budker and Fourmanoir 1954; $3=$ Other records [Map produced with QGIS 2.12.2]

\section{ACKNOWLEDGEMENTS}

We are grateful to Dr. Albert Baranes (HUJ) for collecting highly interesting deep water materials from the Gulf of Aqaba, including the specimen of Tylerius spinosissimus recorded in the present paper, and to Dr. Dor Edelist for collecting the specimen from the Mediterranean coast of Israel (HUJ 19946). 


\section{REFERENCES}

Budker P., Fourmanoir P. 1954. Poissons de la mer Rouge et du golfe de Tadjoura (missions Budker: 1938-39 et Chédeville: 1953). Bulletin du Muséum National d'Histoire Naturelle de Paris, 2e Série 26 (3): 322-325.

Corsini M., Margies P., Kondilatos G., Economidis P.S. 2005. Lessepsian migration of fish to the Aegean Sea: first record of Tylerius spinosissimus (Tetraodontidae) from the Mediterranean, and six more fish records from Rhodes. Cybium 29: 347-354.

Corsini-Foka M., Margies P., Kondilatos G., Economidis P.S. 2010. Tetraodontid colonizers in the Aegean Sea; second record of the spiny blaasop, Tylerius spinosissimus (Actinopterygii: Tetraodontiformes: Tetraodontidae). Acta Ichthyologica et Piscatoria 40 (1): 71-74.

DOI: $10.3750 / A I P 2010.40 .1 .10$

Dor M. 1984. Checklist of the fishes of the Red Sea. CLOFRES. The Israel Academy of Sciences and Humanities, Jerusalem.

Eschmeyer W.N., Fricke R., van der Laan R. (eds.) 2016. Catalog of fishes. Online version, updated 31 March 2016. California Academy of Sciences, San Francisco. http://research.calacademy.org/research/ Ichthyology/Catalog/fishcatmain.asp.

Fricke R. 1983. A method of counting caudal fin rays of actinopterygian fishes. Braunschweiger Naturkundliche Schriften 1 (4): 729-733.

Fricke R. 2015. Twenty-one new records of fish species (Teleostei) from Madang and Papua New Guinea (western Pacific Ocean). Marine Biodiversity Records 8: 1-9. DOI: $10.1017 / \mathrm{S} 1755267215000445$

Fricke R. 2016. References in the Catalog of fishes. Online version, updated 31 March 2016. California Academy of Sciences, San Francisco. http://research.calacademy. org/research/Ichthyology/Catalog/fishcatmain.asp.

Fricke R., Mulochau T., Durville P., Chabanet P., Tessier E., Letourneur Y. 2009. Annotated checklist of the fish species (Pisces) of La Réunion, including a Red List of threatened and declining species. Stuttgarter Beiträge zur Naturkunde A, Neue Serie 2: 1-168.

Golani D., Bogorodsky S.V. 2010. The fishes of the Red Sea-reappraisal and updated checklist. Zootaxa 2463: 1-135.

Golani D., Sonin O., Edelist D. 2011. Second records of the Lessepsian fish migrants Priacanthus sagittarius and Platax teira and distribution extension of Tylerius spinosissimus in the Mediterranean. Aquatic Invasions 6 (Suppl. 1): S7-S11.

Goren M., Dor M. 1994. An updated checklist of the fishes of the Red Sea. CLOFRES II. The Israel Academy of Sciences and Humanities, Jerusalem.

Hardy G.S. 1981. New records of pufferfishes (family Tetraodontidae) from Australia and New Zealand, with notes on Sphoeroides pachygaster (Müller and Troschel) and Lagocephalus sceleratus (Gmelin). National Museum of New Zealand Records 1 (20): 311-316.

Hardy G.S. 1984. Tylerius, a new generic name for the Indo-Pacific pufferfish, Spheroides spinosissimus
Regan, 1908 (Tetraodontiformes: Tetraodontidae) and comparisons with Amblyrhynchotes (Bibron) Duméril. Bulletin of Marine Science 35 (1): 32-37.

Hubbs C.L., Lagler K.F. 1947. Fishes of the Great Lakes Region. Bulletin Cranbrook Institute of Science (Bloomfield Hills, Michigan) No. 26.

Khalaf M., Zajonz U. 2007. Fourteen additional fish species recorded from below $150 \mathrm{~m}$ depth in the Gulf of Aqaba, including Liopropoma lunulatum (Pisces: Serranidae), new record for the Red Sea. Fauna of Arabia 23: 421-433.

Kyushin K., Amaoka K., Nakaya K., Ida H., Tanino Y., Senta T. (eds.) 1982. Fishes of the South China Sea. Japan Marine Fishery Resource Research Center, Tokyo, Japan. [In Japanese and English.]

Larson H.K., Williams R.S., Hammer M.P. 2013. An annotated checklist of the fishes of the Northern Territory, Australia. Zootaxa 3696 (1): 1-293. DOI: 10.11646/zootaxa.3696.1.1

Matsuura K., Tyler J.C. 1997. Tetraodontiform fishes, mostly from deep waters, of New Caledonia. No. 9. In: Séret B. (ed.): Résultats des campagnes MUSORSTOM. Tome 17. Mémoires du Muséum National d'Histoire Naturelle, Paris (Nouvelle Série) (Série A) Zoologie 174: 173-208.

Mohsin A.K.M., Ambak M.A. 1996. Marine fishes and fisheries of Malaysia and neighbouring countries. Kuala Lumpur, Malaysia.

Regan C.T. 1908. Report on the marine fishes collected by Mr. J. Stanley Gardiner in the Indian Ocean. The Transactions of the Linnean Society of London, second Series, Zoology 12 (3): 217-255.

Shao K.-T., Ho H.-C., Lin P.-L., Lee P.-F., Lee M.-Y., Tsai C.-Y., Liao Y.-C., Lin Y.-C. 2008. A checklist of the fishes of southern Taiwan, northern South China Sea. Raffles Bulletin of Zoology, Supplement 19: 233-271.

Smith M.M., Heemstra P.C. 1986. Family No. 268: Tetraodontidae. Pp. 894-903. In: Smith M.M., Heemstra P.C. (eds.) Smiths' Sea Fishes. Macmillan South Africa, Johannesburg, RSA.

Turan C., Yaglioglu D. 2011. First record of the Spiny blaasop Tylerius spinosissimus (Regan, 1908) (Tetraodontidae) from the Turkish coasts. Mediterranean Marine Science 12 (1): 247-252.

Türkay M. 1996. Composition of the deep Red Sea macroand megabenthic invertebrate fauna. Zoogeographic and ecological implications. Pp. 43-59. In: Uiblein F., Ott J., Stachowitsch M. (eds.) Deep-sea and extreme shallow-water habitats: affinities and adaptations. Biosystematics and Ecology Series No. 11.

Zajonz U. 2006. Plectranthias klausewitzi n. sp. (Teleostei, Perciformes, Serranidae), a new anthiine fish from the deep waters of the southern Red Sea. Aqua, International Journal of Ichthyology 12 (1): 19-26.

Received: 19 April 2016

Accepted: 6 May 2016

Published electronically: 30 June 2016 